\title{
“Anak Melecehkan Anak": Dinamika Psikologis Child Neglect sebagai Akar Permasalahan Indikasi Korban Kekerasan Seksual Anak
}

\author{
Berliana Widi Scarvanovi ${ }^{1}$ \\ 1,Universitas Sebelas Maret/Jl. Ir. Sutami No.36A Surakarta \\ e-mail: *1berlianawidi@staff.uns.ac.id
}

\begin{abstract}
The offenders of child sexual abuse turned out not only adult but also other child. This study aims to explore psychological dynamics regarding the indications of victims of child sexual abuse committed by other children through assessment techniques: interviews, observation and psychological test kits. Descriptive analysis study is the data analysis method, the output of this data analysis are history, psychological dynamics and diagnosis of the subject's condition. Based on the results of the assessment, it can be concluded that there are several things that underlie the participant's condition as a victim of sexual harassment. This condition is not a permanent nature of the participant but the response of certain situations in the environment. His condition also relates to the child's social awareness or perception of himself, his relationship with others, and social world. The participant often places himself as a person who succumbs even when he is faced with a situation that is less comfortable for himself. Child neglect that occurs to the participant makes him grows into a quiet and doubtful child. He always seems worried in his interactions with the people around him. The loss of parent figure also makes the participant forced to channel his desire to be loved to others, his desire to be accepted by his environment is very high given the history of rejection by his parents. This condition makes the subject do all the ways to be accepted, one of them by doing oral sex to his friend.
\end{abstract}

Keywords: child sexual abuse, child neglect

\begin{abstract}
Abstrak.Anak sebagai korban kekerasan seksual, ternyata bukan hanya mungkin dilakukan oleh pelaku dewasa namun juga pelaku anak yang lain. Penelitian ini bertujuan untuk menggali dinamika psikologis mengenai indikasi korban kekerasan seksual anak yang dilakukan oleh anak lainnya melalui teknik asesmen: wawancara, observasi dan alat tes psikologi. Metode pengolahan data yang dilakukan adalah studi deskriptif analisis yang menghasilkan anamnesis, dinamika serta diagnosis dari kondisi subjek. Berdasarkan hasil asesmen yang telah dilakukan maka dapat disimpulkan terdapat beberapa hal yang mendasari kondisi subjek sebagai korban dari pelecehan seksual. Kondisi ini salah satunya bukan merupakan sebuah sifat yang menetap dari klien melainkan respon dari situasi tertentu di lingkungannya. Kondisinya juga berkaitan dengan kesadaran sosial atau persepsi anak terhadap dirinya sendiri, hubungan mereka dengan orang lain, dan dunia sosialnya. Dimana subjek sering menempatkan dirinya sebagai orang yang mengalah bahkan ketika dia dihadapkan pada situasi yang kurang nyaman bagi dirinya sendiri.Child neglect yang terjadi kepada subjek membuatnya tumbuh menjadi anak yang pendiam dan peragu. Ia selalu nampak cemas dalam interaksinya dengan orang-orang di sekitarnya. Kehilangan sosok orangtuanya juga membuat subjek terpaksa menyalurkan keinginannya untuk disayangi kepada orang lain, keinginannya untuk diterima oleh lingkungannya sangat besar mengingat histori penolakan yang dilakukan oleh orangtuanya. Kondisi ini membuat subjek melakukan segara cara untuk dapat diterima, salah satunya dengan melakukan oral seks sesuai dengan permintaan temannya.
\end{abstract}

Kata Kunci:kekerasan seksual anak, penelantaran anak

\section{Introduction}

Kasus kekerasan kepada anak sangat sering terjadi, baik di Indonesia ataupun secara umum di wilayah lain di seluruh dunia. Kekerasan kepada anak ini mencakup kekerasan secara 
fisik, emosional, seksual, penelantaran dan eksploitasi yang memiliki potensi atau dampak yang buruk pada kesehatan dan perkembangan anak. Dalam jurnal ini, kekerasan kepada anak yang akan banyak diangkat mengenai kekerasan seksual dan penelantaran. Kekerasan seksual pada anak sendiri mencakup beberapa hal antara lain menyentuh dengan modus seksual, memaksa berhubungan seksual, memaksa anak untuk melakukan tindakan secara seksual, memperlihatkan organ seksual untuk dipertontonkan, prosititusi atau eksploitasi seksual dan lain-lain(Badan Pusat Statistik, 2017).

Secara riil, prevalensi kekerasan terhadap anak di Indonesia masih belum mencakup semua kasus yang terjadi. Hal ini disebabkan karena pelaporan kasus yang cenderung underestimate atau lebih rendah dari angka sebenarnya. Sebuah survey dilakukan untuk melihat prevalensi kekerasan seksual yang terjadi pada anak. Berdasarkan survey tersebut, diketahui bahwa prevalensi kekerasan seksual pada remaja kelompok umur 18-24 tahun yang mengalami kekerasan seksual sebelum usia 18 tahun jumlahnya hamper sama antara laki-laki dan perempuan yaitu sekitar 6\%. Artinya 1 dari 15 orang berumur 18-24 tahun pernah mengalami kekerasan seksual sebelum berusia 18 tahun. Pada survey yang dilakukan di rentang usia 13-17 tahun, dengan kriteria pernah mengalami kekerasan seksual pada 12 bulan terakhir menghasilkan angka 8,3\% pada laki-laki dan 4,1\% pada perempuan (Kurniasari, et al., 2013). Berdasarkan data dari Lembaga Perlindungan Saksi Korban (LPKS), korban pelecehan seksual pada anak terus meningkat dari tahun ke tahun. LPKS dapat menerima laporan mengenai kasus pelecehan seksual anak setidaknya 4 kali dalam seminggu (Alfons, 2019). Prevalensi kekerasan seksual anak menurut KPAI, terdapat 21 kasus kekerasan seksual dengan korban sebanyak 123 anak. Terdiri dari 71 perempuan dan 52 laki-laki (Moerti, 2019).

Pelaku kekerasan seksual yang terjadi kepada anak rata-rata dilakukan oleh orang dewasa yang berada di sekitar anak. Namun, dalam beberapa kasus terdapat fakta yang menunjukkan bahwa anak dapat melakukan kekerasan seksual kepada anak yang lain. Berdasarkan survey di Amerika Serikat terdapat $35,6 \%$ anak-anak yang menjadi pelaku kekerasan seksual (Liputan6com, 2020). Beberapa hal yang dapan menjadi pemicu anak menjadi pelaku kekerasan seksual antara lain, pengalaman kekerasan seksual yang pernah terjadi di masa lalu, serta paparan pornografi dan pornoaksi. Pelaku juga cenderung tidak merasa bersalah karena mereka pernah diperlakukan sama oleh orang lain di sekitarnya. Sedangkan anak dapat menjadi korban kekerasan seksual karena kemampuan kognitif anak yang masih cenderung belum matang, sementara kemampuan seksualnya sudah mulai tumbuh. Anak pada dasarnya belum dapat menangkap konsep seksualitas, termasuk norma dan batasannya, sehingga anak cenderung tidak memahami apa yang terjadi padanya. Keterbatasan ini yang kemudian membuat anak sulit mengungkapkan apa yang terjadi kepada orangtuanya (Wahyudi, 2014). 
Kekerasan seksual yang terjadi tentunya menciptakan dampak tersendiri bagi anak. Beberapa dampak dari kekerasan seksual yang terjadi pada anak antara lain: gangguan fisik yaitu menurunnya nafsu makan, kesulitan tidur, pusing, gangguan di alat kelamin, bahkan kehamilan yang tidak diinginkan. Secara psikologis, kekerasan seksual dapat mengakibatkan korban merasa cemas dan depresi, PTSD, gangguan identitas disosiatif dan gangguan kepribadian (Levitan, Rector, Sheldon, \& Goering, 2003); kecenderungan untuk reviktimisasi di masa yang akan datang juga cukup besar (Dinwiddie, et al., 2000). Dampak jangka pendek dari kekerasan seksual anak antara lain: ketakutan yang berlebihan kepada orang lain, mimpi buruk, dan kurang konsentrasi, sedangkan jangka panjang adalah munculnya fobia, atau gangguan sadism dan masokisme (Weber \& Smith, 2010). Dampak lain dari kekerasan seksual antara lain: pengkhanatan atau rasa kurang percaya kepada orang lain, trauma seksual, merasa tidak berdaya, sigmatisasi diikuti perasaan malu, bersalah dan gambaran diri yang buruk (Tower, 2002).

Penelitian ini berfokus kepada anak sebagai korban kekerasan seksual yang dilakukan oleh anak lain. Beberapa penyebab seorang anak menjadi korban dari kekerasan seksual adalah pendidikan dan kondisi pernihakan orangtua, menurut sebuah penelitian, salah satu yang menyebabkan risiko terjadinya kekerasan seksual anak adalah perceraian orangtua (Datulinggi, Thaha, Zulkifli, \& Mallongi, 2020); anak yang menunjukkan simtom depresi dan anak dengan kebutuhan khusus juga merupakan populasi yang rentan mengalami kekerasan seksual (Ngo, Veliz, Kusunoki, Stein, \& Boyd, 2018);penggunaan obat-obatan terlarang (Basile, Clayton, Rostad, \& Leemis, 2020); kehangatan dalam keluarga (Abdillah, Andayani, \& Scarvanovi, 2019); neglect yang dilakukan orangtua juga merupakan salah satu penyebab utama rentannya anakanak menjadi korban kekerasan seksual (Liel, et al., 2020).

Child neglect sendiri artinya kondisi dimana orangtua melepaskan tanggung jawab dan klaim atas keturunan, anak tersebut kemudian ditinggalkan dan tidak diurus oleh orangtuanya (UNICEF, 2014). Anak-anak yang ditelantarkan oleh orangtuanya tumbuh menjadi anak yang mengalami hambatan perkembangan dan kurang sejahtera (well-being) (Blaisdell, Imhof, \& Fisher, 2019); trauma dan meningkatnya dorongan untuk bunuh diri (Vanderminden, et al., 2019); kecemasan (Tonmyr, Williams, Hovdestad, \& Draca, 2011); serta meningkatkan risiko anak terlibat dalam perilaku seksual yang berisiko (memiliki banyak pasangan seksual hingga hubungan seksual secara anal) (Diaz, et al., 2020). Child neglect terbukti sebagai salah satu faktor yang berkontribusi kepada kondisi psikologis anak yang menyebabkannya rentan melakukan perilaku seksual berisiko serta menjadi korban kekerasan yang lain. Latar belakang inilah yang mendorong penelitian mengenai child neglect sebagai sebuah akar permasalahan dari indikasi korban pelecehan seksual anak.Sehingga tujuan dari penelitian ini adalah menggali 
dinamika psikologis mengenai indikasi korban kekerasan seksual anak yang dilakukan oleh anak lain.

\section{Methods}

Metode yang digunakan dalam pengambilan data (asesmen) dalam penelitian ini adalah:

1. Wawancara dan Observasi

Wawancara dilakukan dengan metode wawancara semi terstruktur (Sugiyono, 2012). Wawancara yang dilakukan berdasar pada pedoman diagnostik, dilakukan kepada subjek serta keluarga subjek. Observasi yang dilakukan adalah observasi naturalistik. Kedua metode tersebut digunakan untuk memahami anamnesis gangguan subjek serta sebagai dasar penegakan diagnosis.

2. Alat Tes Psikologi

Beberapa alat tes psikologi digunakan dalam penelitian ini, yaitu Standford-Binet Intteligence Test yang bertujuan untuk melihat kemampuan intelektual subjek terkait dengan kemampuan subjek untuk memahami kondisi di sekitarnya dan melakukan pemecahan masalah, serta digunakan untuk menentukan diagnosis serta intervensi yang dapat dilakukan untuk subjek. Vineland Social Maturity Scale (VSMS) yang bertujuan untuk melihat kematangan sosial subjek. Child behavioral checklist yang bertujuan untuk untuk mengetahui perilaku subjek yang kurang adaptif. Forer sentence completion test (FSCT) digunakan untuk melihat adjustment subjek terhadap lingkungannya, sehingga didapat gambaran proyeksi hal-hal yang mengganggu subjek terkait dengan lingkungan. Yang terakhir adalah grafis yang digunakan untuk mengetahui persepsi subjek mengenai dirinya sendiri, persepsi subjek tentang lingkungannya, serta sosok orangtua bagi subjek, sehingga akan ditemukan pendekatan yang sesuai untuk intervensi subjek.

Metode analisis yang digunakan dalam penelitian ini adalah studi deskriptif analisis. Metode deskriptif analisis sendiri adalah sebuah metode kualitatif dalam penggalian fakta atau kondisi sebagaimana mestinya sebagai upaya pengambilan kesimpulan dengan cara menggambarkan keadaan objektif atau peristiwa tertentu (Nawawi \& Martini, 1994). Metode ini juga berfungsi untuk menelaah masalah yang sedang terjadi saat ini (Supardan, 2009). Studi ini bertujuan untuk mendapat data yang mengandung makna dan mendalam (Sugiyono, 2012). Dalam penelitian ini, metode deskriptif analisis bertujuan untuk menyusun dinamika subjek secara utuh, terutama mengenai bagaimana pola pengasuhan neglect yang terjadi kepada subjek mempengaruhi aspek-aspek kepribadiannya sehingga memunculkan perilaku-perilaku yang khas/khusus. 


\section{WACANA}

\section{Results}

Untuk mendapatkan sebuah dinamika psikologi yang utuh maka hasil penelitian akan dipaparkan dalam beberapa bagian, antara lain:

\section{Anamnesis}

Berdasarkan hasil wawancara dan observasi yang telah dilakukan, terdapat beberapa hasil anamnesis mengenai subjek penelitian. Berikut meruupakan dinamika anamnesis berdasarkan hasil wawancara dan observasi. Ketika pengambilan data dilakukan, subjek merupakan salah satu penghuni UPTD untuk anak jalanan di Surabaya. Subjek berjenis kelamin laki-laki dan berusia 10 tahun dengan keluhan sebagai berikut:

Sebelum masuk ke UPTD subjek tidak pernah melakukan aktivitas seksual. Ketika subjek masuk ke asrama UPTD terdapat seorang anak yang mempengaruhi teman-temannya untuk melakukan aktivitas seksual seperti oral seks serta intercourse. Kemudian seorang anak baru masuk ke dalam asrama. Anak tersebut pernah membayar orang lain untuk melakukan hubungan dengannya, dia juga pernah dibayar oleh orang lain untuk berhubungan seksual sebelum dia masuk ke dalam asrama. Anak tersebut kemudian mulai menyuruh subjek untuk melakukan oral seks padanya. Kegiatan tersebut dilakukan di area aula, kamar, dan kamar mandi. Dari laporan yang diterima UPTD, keduanya setidaknya telah melakukan oral seks tersebut sebanyak 5 kali, meskipun jumlah pastinya tidak dapat diketahui karena tidak adanya kamera CCTV di area kamar mandi.

Berdasarkan permasalahan tersebut, digalilah data mendalam mengenai subjek. Subjek adalah anak kedua dari 4 bersaudara. Ibunya bekerja dengan berjualan katering kecil, sedangkan ayah kandungnya bekerja sebagai tukang bangunan. Ketika menikah dengan ayah kandungnya, ibu subjek memiliki 2 orang anak, kakak subjek dan subjek sendiri. Ayah kandung subjek adalah orang yang suka bersikap kasar dengan memukul ibu dan anak-anaknya sendiri. Dia juga seorang yang pencemburu. Hal tersebut yang membuat ibu subjek dan ayahnya kemudian bercerai. Ayah kandung subjek membawa kakak subjek, sedangkan subjek dibawa oleh ibunya. Subjek berumur sekitar 2 tahun pada saat perceraian orangtuanya tersebut.

Setelah itu, subjek dititipkan oleh ibunya pada neneknya, hingga saat ini ayah dan kakaknya tidak lagi diketahui keberadaannya. Subjek dibesarkan oleh neneknya selama 1 tahun, ketika subjek berusia sekitar 3 tahun ibunya kembali dengan kondisi sudah menikah lagi. Ayah tiri subjek bekerja sebagai seorang supir. Dari pernikahan tersebut, ibu subjek dikaruiniai 2 orang anak. Subjek sendiri sangat menyayangi kedua adiknya, dia selalu bermain bersama dan membagi makanan atau apapun yang didapatkannya pada adik-adiknya. Ketika subjek berusia 9 tahun, ibu subjek dan ayah tirinya bercerai disebabkan oleh permasalahan kecemburuan dikarenakan ibu subjek yang sering tidak pulang ke rumah karena pekerjaannya. Ayah tiri subjek kemudian membawa adiknya pergi dari rumah dan meninggalkan subjek dengan ibunya. 
Setelah kepergian suaminya, ibu subjek kemudian menyerahkan subjek di bawah pengasuhan neneknya lagi dan pergi dari rumah. Saat ini keberadaan ayah tiri dan ibu subjek tidak diketahui. Ibu subjek terkadang memberikan kabar atau informasi keberadaannya pada nenek subjek, namun setiap kali dicari akan berakhir pada alamat palsu. Ibu subjek tidak pernah tinggal di sana atau alamat yang dicari tidak ada. Ketika dalam asuhan neneknya, ibu subjek tidak pernah menengok subjek sama sekali ataupun memberikan uang untuk menghidupi subjek. Neneknya mengaku bahwa ketika subjek kembali dalam asuhannya subjek mulai bersikap aneh dengan sering bermain PS di pinggir jalan raya dan beberapa kali pergi tanpa pamit. Neneknya pun setiap kali harus pergi untuk mencarinya. Ketika neneknya memintanya untuk membuang sampah, subjek tidak kembali sama sekali, hingga pihak UPTD mengantarkannya 2 bulan setelahnya. Selama tenggang 2 bulan tersebut neneknya mengaku bahwa ibu subjek mencari-cari subjek, namun mereka tidak melaporkan hilangnya subjek pada polisi. Nenek subjek pun tidak pernah menjenguk subjek karena alasan kesehatan dan sulitnya transportasi ke sana.

Tubuh subjek terlihat kecil untuk anak berusia 10 tahun, tapi menurut tetangganya saat ini subjek terlihat bersih dan terawat dibandingkan dengan kondisinya saat masih tinggal bersama neneknya dan belum masuk ke dalam UPTD. Subjek tidak mau masuk ke dalam rumah ketika pertama kali diantarkan pulang. Subjek takut dia tidak akan dibawa kembali ke UPTD. Pembimbing juga menyatakan bahwa subjek dibentak oleh neneknya ketika dia pulang dan neneknya bertanya kenapa subjek harus pulang ke rumah dan tidak tinggal saja di UPTD.

Subjek tidak pernah mendapatkan pendidikan formal sama sekali. Ketika dia cukup umur untuk masuk ke TK, neneknya berniat untuk mendaftarkannya. Namun, subjek tidak memiliki surat resmi seperti kartu keluarga, sehingga pihak TK pun menolak subjek. Sejak saat itu subjek tidak bersekolah sama sekali. Setiap hari dia hanya bermain di rumah.Satu-satunya pendidikan yang diterima oleh subjek adalah pembimbingan kognitif yang dilakukan di UPTD setiap hari Senin hingga Rabu pada pukul 08.00-11.00. Pembimbingan kognitif tersebut dibagi menjadi dua bagian yaitu baca dan berhitung. Saat ini subjek dapat membaca dengan cara mengeja. Subjek dapat membaca kata dengan 2 suku kata di dalamnya, meskipun masih sering melakukan kesalahan ketika harus membaca kata dengan huruf konsonan di akhir kata. Subjek juga dapat menulis dengan cara dieja dan dengan bantuan dari orang lain. Ketika menulis, subjek juga terkadang melakukan kesalahan, misalnya huruf yang tertukar dalam satu kata. Contohnya, ketika dia ingin menulis 'laki', subjek menulisnya menjadi 'laik'.

Dalam perhitungan matematika, subjek mampu melakukan operasi aritmatika berupa penambahan dan pengurangan. Hingga saat ini, subjek dapat menyelesaikan perhitungan yang setara dengan anak kelas 2 SD. Subjek mampu menyelesaikan soal penambahan ratusan dengan 
cara menyusun ke bawah. Hingga saat ini subjek masih belum memahami operasi pengurangan, perkalian, dan pembagian.

Setelah tinggal di UPTD, subjek yang berbadan kecil sering menjadi objek pemukulan anak-anak yang lebih besar darinya. Subjek sendiri jarang membalas atau hanya memukul dengan ringan ketika membalas. Begitu pula ketika temannya bermain game di handphone milik pembimbing atau orang lain, subjek terkadang tidak mendapatkan kesempatan untuk ikut bermain karena temannya tidak memberikan kesempatan padanya. Saat itu subjek hanya diam dan melihat teman-temannya bermain.Subjek jarang memulai sebuah pembicaraan terlebih dahulu, baik pada orang yang belum dikenal maupun pada orang yang berada di sekelilingnya. Dia kebanyakan hanya duduk atau bermain sendirian.

Sebelum di bawa ke UPTD subjek tidak pernah melakukan aktivitas seksual sama sekali. Namun, setelah dia masuk ke dalam asrama, salah seorang temannya sering mengajak temannya yang lain untuk melakukan hubungan seksual. Temannya tersebut juga sering mempengaruhi anak-anak di UPTD untuk melakukan perilaku yang sama. Beberapa bulan setelah subjek masuk ke UPTD, seorang anak baru masuk ke asrama, anak tersebutlah yang kemudian sering menyuruh subjek melakukan oral seks padanya. Menurut subjek, selama beberapa kali melakukan oral seks tersebut temannya tidak pernah mencapai klimaks. Namun perilaku tersebut diulang beberapa kali, atau sekitar 5 kali dalam laporan pada UPTD. Hingga saat ini belum dapat dihitung secara pasti berapa kali perbuatan tersebut dilakukan karena beberapa kali oral seks tersebut dilakukan di kamar mandi yang tidak memiliki CCTV. Subjek sendiri telah diadukan oleh temannya yang mengatakan bahwa subjek memintanya melakukan oral seks dengan iming-iming uang.

\section{Hasil Tes}

\section{a. Standford-Binet Intelligence Test}

Subjek memiliki IQ sebesar 58 yang berarti kemampuan subjek berada di bawah anak-anak seumurannya atau setara dengan anak-anak yang berusia 5 tahun 11 bulan. Subjek saat ini memang berusia 10 tahun, namun kemampuannya setara dengan anak berusia 5 tahun 11 bulan yang biasanya baru masuk ke bangku sekolah dasar.

Kemampuan subjek yang paling menonjol terletak pada konstrak yang tidak hanya distimulasi dari lingkungan sekolah misalnya kemampuan visual-motornya dan kemampuan penalarannya terhadap situasi di lingkungannya. Meskipun demikian, kedua kemampuan tersebut masih berada di bawah umur kronologis subjek saat ini. Kemampuan subjek lebih rendah pada konstrak yang harus banyak mendapatkan stimulasi dari lingkungan sekolah. Misalnya kemampuan aritmatika, kemampuan kosakata dan verbal subjek serta kemampuan ingatan subjek. 
Pemahaman konsep subjek masih terbatas pada hal-hal yang kongkrit, dimana subjek harus diberi stimulus secara visual untuk mempermudah pemahaman subjek. Subjek akan mengalami kesulitan untuk memahami suatu hal jika stimulus yang diberikan hanya dalam bentuk verbal.

Ditinjau dari latar belakangnya yang tidak pernah duduk di bangku pendidikan formal dan subjek yang kurang mendapat stimulasi dari orang-orang di sekitarnya, maka kemampuan subjek masih di area kongkrit. Subjek masih kesulitan untuk berpikir secara abstrak. Hal tersebut memang setara dengan anak-anak yang baru saja lulus dari TK dan baru masuk SD, sesuai dengan umur mental subjek.

\section{b. Vineland Social Maturity Scale}

Kematangan sosial subjeksetara dengan anak usia 9 tahun. Nilai subjek cukup tinggi terutama pada tugas-tugas yang tidak menuntutnya untuk membaca atau melakukan halhal yang diajarkan di sekolah. Subjek mampu melakukan hal-hal yang berhubungan dengan pekerjaan. Sebagai contoh, subjek mampu mencuci sendiri dan melakukannya secara rutin juga melakukan keterampilan-keterampilan yang diajarkan di UPTD yang dapat digunakannya sebagai mata pencaharian ketika dia dewasa nanti. Subjek juga mampu mengurus dirinya sendiri seperti memakai pakaian sendiri, mandi sendiri dan memakai pakaian rapi. Subjek juga sudah memahami mata uang hingga pecahan Rp50.000 sehingga mampu berbelanja sendiri.

Nilai subjek pada aspek komunikasi cukup tinggi, atau sesuai dengan umur subjek. Hal tersebut disebabkan karena subjek mampu menggunakan telepon, meskipun demikian subjek yang belum dapat membaca dan menulis dengan lancar mengalami kesulitan dalam area tersebut. Aspek dari kematangan sosial subjek yang paling rendah adalah self help general yang setara dengan anak berusia 4 tahun. Hal tersebut disebabkan karena hingga saat ini subjek tidak dapat memahami waktu atau jam.

\section{c. Child Behavioral Checklist}

Beberapa sub bagian dari CBCL menunjukkan bahwa subjek mengalami permasalahan di area tertentu. Dari 8 permasalahan yang diungkap dengan CBCL, lima diantaranya berada di atas garis batas klinis yaitu withdrawn, anxious/depressed, social problem, attention problem, dan delinquent behavior. Berdasarkan hasil wawancara dan observasi terkait dengan CBCL, subjek memang mengalami permasalahan di area social problem, attention problem, dan delinquent behavior. Subjek terlihat sangat manja dan membutuhkan sosok yang jauh lebih tua darinya, sehingga dia lebih banyak bergaul dan berbicara dengan orang yang lebih tua darinya. Berkebalikan dengan hal tersebut hubungan subjek dengan teman yang seumuran dengannya tidak berjalan dengan baik. Subjek yang sering dianggap usil oleh teman-temannya (memberi makan ikan yang 
dipancing temannya pada kucing, mengerjai teman-temannya) kemudian sering diganggu oleh teman-temannya. Subjek mudah merasa takut terutama jika diganggu oleh temantemannya sehingga dia akhirnya lebih banyak bermain sendirian.

Permasalahan atensi yang terjadi pada subjek lebih banyak terkait dengan performansi subjek di kelas kognitif. Subjek sulit berkonsentrasi di dalam kelas, dia harus ditemani secara khusus untuk menjaga konsentrasinya pada pelajaran. Subjek juga mudah teralih perhatiannya terutama jika temannya berbicara, meskipun temannya tersebut berbicara dengan orang lain dan tidak mengajak subjek berbicara. Dia juga sering tidurtiduran di ruangan kelas. Subjek juga terkadang merasa bingung ketika diajak berbicara karena kurang dapat menangkap apa yang orang minta atau tanyakan darinya.

Terkait dengan deliquent behavior subjek sering mengelak ketika melakukan suatu kesalahan, meskipun pada akhirnya dia mengakui telah melakukan kesalahan. Subjek juga pernah melarikan diri dari rumah hingga dia dibawa oleh Satpol PP, saat itupun subjek lebih banyak bermain dengan teman-teman yang lebih tua di tempat bermain Playstation. Subjek juga mudah dipengaruhi oleh teman-temannya sehingga permasalahan terkait seks disebabkan oleh pengaruh teman-temannya. Subjek pernah bermain dengan alat kelaminnya sendiri dan melakukan oral seks pada temannya yang lain. Karena pengalaman tersebutlah dia meminta temannya yang lain melakukan oral seks padanya.

\section{d. Forer Sentence Completion Test (FSCT)}

Figur ayah bagi diri subjek adalah orang yang kerap bertengkar dengan ibunya, sedangkan ibunya adalah orang yang selalu memenuhi kebutuhannya. Subjek pada dasarnya memiliki keinginan agar kedua orangtuanya menjemputnya untuk dibawa pulang. Persepsi subjek terhadap kelompok anak laki-laki dan perempuan terbatas pada anak-anak yang bermain di sekelilingnya, karena subjek keterbatasan teman-teman yang dimiliki oleh subjek. Hal yang saat ini menjadi keinginan subjek yang paling besar adalah keinginannya untuk bersekolah. Subjek sangat ingin dapat membaca seperti teman-temannya, bahkan subjek menyisihkan uang agar dirinya dapat bersekolah.

\section{e. Grafis}

Subjek merasakan ketidaknyamanan dalam hubungannya dengan orang lain yang disebabkan karena rasa kurang percaya diri. Subjek juga merasakan perasaan inferior dalam hubungannya dengan orang di sekelilingnya, sehingga dia cenderung menutup dirinya. Selain itu, dia juga merasa perasaan tertekan dan tidak pasti sehingga dirinya cenderung memaksakan dirinya dalam hubungan dengan orang lain. Hubungan antara subjek dengan keluarganya kurang baik, namun subjek masih mengharapkan kasih sayang dari kedua orangtuanya. Peran kedua orangtuanya terlihat samar dan tidak jelas bagi subjek. 


\section{WACANA}

\section{Dinamika Psikologis}

Subjek memiliki kebutuhan dependensi yang cukup besar, namun ayahnya telah meninggalkannya sejak kecil, sedangkan ibunya tidak pernah memberikan perhatian yang subjek butuhkan. Di tengah kebutuhan subjek akan kasih sayang dari orang lain, subjek pun telah kehilangan figur lekatnya. Dampaknya, subjek berusaha memproyeksikan kebutuhannya akan kasih sayang tersebut pada orang-orang di sekitarnya yang lebih tua darinya.

Kehilangan figur yang memberikan kasih sayang padanya membuat subjek merasakan inferioritas. Perasaan ini juga ditunjang dengan kondisi subjek yang kurang mendapatkan stimulus secara kognitif sejak dirinya kecil, membuat pemikiran subjek masih terbatas dalam area kongkrit dan bukan area abstrak seperti perkembangan umurnya. Keduanya membentuk subjek menjadi orang yang mudah dipengaruhi oleh lingkungan di sekitarnya.

Respon subjek terhadap lingkungannya pun menjadi kurang adaptif. Subjek menjadi anak yang lebih sering melakukan kegiatan sendirian dan mudah merasakan perasaan bersalah meskipun tidak melakukan kesalahan apapun. Kepribadian subjek yang mudah terpengaruh lingkungan serta kemampuan kognitif subjek yang terbatas membuatnya terseret dalam kegiatan seksual yang dilakukan oleh beberapa temannya. Subjek yang sering melakukan oral seks pada temannya kemudian meminta orang lain melakukan oral seks padanya.

\section{Diagnosis}

Berdasarkan Pedoman Penggolongan dan Diagnosis Gangguan Jiwa (PPDGJ-III), maka pemeriksa menyimpulkan diagnosis subjek. Kondisi yang menjadi fokus perhatian klinis pada subjek adalah indikasinya sebagai korban kekerasan seksual anak, yang dilakukan oleh anak lain. Disebut indikasi karena saat pengambilan data tidak ada bukti secara medis mengenai kekerasan seksual yang terjadi kepada subjek, sehingga kesimpulan berdasarkan kepada asesmen psikologis yang sudah dilakukan. Subjek mengalami Gangguan kelekatan reaktif masa kanak(F94.1), yaitu gangguan fungsi sosial yang terjadi pada tahap perkembangan anak atau remaja dan tidak ditandai dengan suatu ketidakmampuan atau defisity konstitusi sosial. Terdapat pola abnormal dalam hubungan anak dengan para pengasuhnya yang timbuh sebelum anak mencapai usia 5 tahun, yang timbul sebelum anak mencapai usia 5 tahun. Gangguan ini berkaitan dengan pengasuhan anak yang kurang memadai. Hal ini mungkin dalam bentuk penganiayaan psikologis atau penelantaran (sikap kurang memperhatikan kebutuhan fisik anak, berulangkali sengaja mencederai anak, atau kurang memberikan makanan bergizi).

Secara umum, penelitian ini tidak menemukan riwayat medis yang relevan dengan kondisi subjek saat ini. Subjek mengalami permasalahan psikososial dan lingkungan yaitu Neglect of Child(T.74.0), ditandai dengan kondisi subjek yang ditinggalkan oleh ibunya sejak anak-anak, tdak memiliki kelekatan secara emosi dengan nenek yang mengasuhnya, sering berkeliaran di jalan raya, serta tidak mendapatkan pendidikan sejak kecil. Keseluruhan 


\section{WACANA}

gambaran psikologis subjek tersebut membuat subjek mengalami kesulitan ringan di area sosial, pekerjaan, dan sekolah (GAF51-60).

\section{Discussion}

Tingkat intelegensi subjek adalah 58 yang berada di jauh di bawah rata-rata atau setingkat dengan anak yang mengalami retardasi mental (mild mental retardation) (Sattler, 2002). Namun untuk penegakan diagnosis retardasi mental diharuskan terdapat setidaknya dua perilaku yang tidak adaptif. Dengan pertimbangan bahwa subjek memiliki kematangan sosial yang cukup baik atau setara dengan anak berumur 9 tahun dan subjek tidak memiliki permasalahan yang menonjol pada perilaku adaptif kecuali subjek yang belum mampu membaca dan menulis dengan lancar. Maka disimpulkan bahwa tingkat intelegensi subjek yang rendah disebabkan oleh kurangnya stimulasi secara kognitif semenjak subjek kecil (DSM-IVTM, 1994).

Menurut teori behaviorisme perilaku anak yang abnormal ataupun tidak adaptif serta bagaimana anak mempersepsi lingkungannya dibentuk oleh kognisi dan hasil belajar anak. Teori ini berlandaskan pada pengaplikasian konsep kognitf untuk memahami suatu perilaku (Mash \&Wolfe, 2010). Seperti perilaku subjek saat ini yang dianggap bermasalah yaitu melakukan oral seks, menurut teori behaviorisme hal tersebut terjadi karena respon dari situasi tertentu di lingkungannya dibandingkan dari sifat yang menetap pada diri subjek. Menurut teori Social Learning, perilaku yang dibentuk oleh anak bukan hanya berdasarkan dari mencontoh perilaku orang lain secara langsung, namun juga muncul karena proses kognitif baik secara langsung maupun tidak langsung. Perilaku yang muncul pada anak bukan hanya hasil dari adanya penguatan positif dan negatif ataupun stimulus yang terkondisikan namun juga karena hal-hal yang bersifat tidak langsung seperti mengobservasi perilaku orang lain. Teori ini sesuai dengan perilaku oral seks subjek tidak pernah mendapatkan penguatan secara langsung. Subjek hanya mengamati bahwa ketika dia melakukan oral seks pada temannya, temannya tersebut akan merasa enak. Karena itulah subjek kemudian meminta orang lain melakukan hal tersebut padanya.

Social learning juga berpendapat bahwa peran anak dalam lingkungan sosial juga mempengaruhi bagaimana sebuah perilaku terbentuk. Peran anak dalam sebuah lingkungan sosial disebut dengan kesadaran sosial. Kesadaran sosial berkaitan dengan bagaimana persepsi anak terhadap dirinya sendiri, hubungan mereka dengan orang lain, dan dunia sosialnya. Kesadaran sosial ini bukan merupakan suatu hal yang tidak dapat berubah, hal ini dapat berubah seiring dengan kedewasaan dan interaksi sosial anak (Mash \& Wolfe, 2010). Ditinjau dari hubungan subjek dengan teman-temannya, subjek sering menempatkan dirinya sebagai orang yang mengalah bahkan ketika dia dihadapkan pada situasi yang kurang nyaman bagi 
dirinya sendiri. Hal tersebut menyebabkan subjek lebih memilih berinteraksi dengan orang yang lebih tua darinya.

Perkembangan kognitif anak dalam penalaran dan penyelesaian masalah membantu mereka menemukan siapa diri mereka sebenarnya dan bagaimana dirinya terhubung dengan orang-orang di sekitarnya. Social Learning juga mempertimbangkan pengaruh variabel konteksual seperti keluarga dan teman sebaya kepada perilaku anak (Mash \& Wolfe, 2010). Subjek yang sebelumnya tidak pernah melakukan aktivitas seksual di luar UPTD terpengaruh oleh teman sebayanya yang pernah melakukan hal tersebut di luar UPTD. Dengan keterbatasan perkembangan kognitif subjek ditambah stimulasi yang didapatkan dari teman sebayanya, perilaku subjek kemudian berubah menjadi tidak adaptif dengan melakukan oral seks pada orang lain dan meminta temannya melakukan oral seks padanya.

Ditinjau dari kondisi lingkungan subjek, terdapat beberapa kondisi yang mendorong subjek kepada situasi rentan mengalami kekerasan seksual. Salah satunya adalah perceraian kedua orangtuanya, hal ini juga tidak hanya terjadi sekali dalam kehidupan subjek, melainkan dua kali. Kondisi psikologis yang rentan pasca perceraian ini yang dapat menjadi salah satu penyebab kerentanan pada subjek. Hal ini sesuai dengan penelitian yang menyebutkan bahwa salah satu yang menyebabkan risiko terjadinya kekerasan seksual anak adalah perceraian orangtua (Datulinggi, Thaha, Zulkifli, \& Mallongi, 2020); kehangatan dalam keluarga (Abdillah, Andayani, \& Scarvanovi, 2019). Setelah bercerai dengan suaminya, baik yang pertama ataupun yang kedua, ibu subjek cenderung meninggalkan subjek kepada nenek subjek hingga waktu yang tidak ditentukan. Kondisi ini merupakan salah satu bentuk dari child neglect yang dilakukan oleh orangtua. Neglect yang dilakukan orangtua juga merupakan salah satu penyebab utama rentannya anak-anak menjadi korban kekerasan seksual (Liel, et al., 2020).

Child neglect yang terjadi kepada subjek membuatnya tumbuh menjadi anak yang pendiam dan peragu. Ia selalu nampak cemas dalam interaksinya dengan orang-orang di sekitarnya, hal ini sesuai dengan dampak dari child neglect yaitu kecemasan (Tonmyr, Williams, Hovdestad, \& Draca, 2011). Kehilangan sosok orangtuanya juga membuat subjek terpaksa menyalurkan keinginannya untuk disayangi kepada orang lain, keinginannya untuk diterima oleh lingkungannya sangat besar mengingat histori penolakan yang dilakukan oleh orangtuanya. Kondisi ini membuat subjek melakukan segara cara untuk dapat diterima, salah satunya dengan melakukan oral seks sesuai dengan permintaan temannya, meskipun ia tidak memahami hal tersebut. Hal ini membuktikan bahwa child neglect dapat meningkatkan risiko anak terlibat dalam perilaku seksual yang berisiko (Diaz, et al., 2020). 


\section{WACANA}

\section{Conclusion}

Penelitian ini menyoroti kasus mengenai indikasi korban kekerasan seksual terhadap anak yang dilakukan oleh anak lainnya. Berdasarkan hasil asesmen yang telah dilakukan maka dapat disimpulkan terdapat beberapa hal yang mendasari kondisi subjek sebagai korban dari pelecehan seksual. Kondisi ini salah satunya bukan merupakan sebuah sifat yang menetap dari klien melainkan respon dari situasi tertentu di lingkungannya. Kondisinya juga berkaitan dengan kesadaran sosial atau persepsi anak terhadap dirinya sendiri, hubungan mereka dengan orang lain, dan dunia sosialnya. Dimana subjek sering menempatkan dirinya sebagai orang yang mengalah bahkan ketika dia dihadapkan pada situasi yang kurang nyaman bagi dirinya sendiri.

Child neglect yang terjadi kepada subjek membuatnya tumbuh menjadi anak yang pendiam dan peragu. Ia selalu nampak cemas dalam interaksinya dengan orang-orang di sekitarnya. Kehilangan sosok orangtuanya juga membuat subjek terpaksa menyalurkan keinginannya untuk disayangi kepada orang lain, keinginannya untuk diterima oleh lingkungannya sangat besar mengingat histori penolakan yang dilakukan oleh orangtuanya. Kondisi ini membuat subjek melakukan segara cara untuk dapat diterima, salah satunya dengan melakukan oral seks sesuai dengan permintaan temannya, meskipun ia tidak memahami hal tersebut.

\section{Implication}

Penelitian mengenai kekerasan seksual terutama yang dilakukan oleh anak kepada korban anak masih sangat jarang diteliti, sehingga ke depannya terdapat beberapa hal yang dapat dikembangkan menjadi penelitian lanjutan. Kedepannya penelitian dapat lebih berfokus kepada faktor penyebab mengapa banyak sekali kasus kekerasan seksual kepada anak tidak banyak tergali, bahkan fenomenanya digambarkan seperti gunung es. Kerentanan seorang anak menjadi korban pelecehan seksual oleh anak yang lain juga menjadi sebuah sisi yang layak untuk diteliti lebih jauh. Tentunya bagaimana karakteristik anak sebagai korban akan berbeda jika yang melakukan adalah anak yang lain dibandingkan dengan orang dewasa. Berdasarkan karakteristik perkembangan sendiri, orang dewasa mungkin melakukan manipulasi ataupun pemaksaan, namun kondisi anak sebagai pelaku memiliki dinamika lain yang juga layak untuk diteliti lebih jauh.

\section{References}


Abdillah, H., Andayani, T. R., \& Scarvanovi, B. W. (2019). Intensitas Penggunaan Komunikasi Bermedia dan Kehangatan dalam Pertemanan pada Siswa SMA di Surakarta. Indigenous: Jurnal Ilmiah Psikologi, 4 (1), 52-60.

Alfons, M. (2019, Juli 24). DetikNews. Retrieved from DetikNews: https://news.detik.com/berita/d-4637744/lpsk-kasus-kekerasan-seksual-pada-anakmeningkat-tiap-tahun

Badan Pusat Statistik. (2017). Statistik Gender Tematik - MEngakhiri Kekerasan Terhadap Perempuan dan Anak di Indonesia. Jakarta: Kementerian Pemberdayaan Perempuan dan Perlindungan Anak.

Basile, K. C., Clayton, H. B., Rostad, W. L., \& Leemis, R. W. (2020). Sexual Violence Victimization of Youth and Health Risk Behaviors. American Journal of Preventive Medicine Volume 58, Issue 4, 570-579.

Blaisdell, K. N., Imhof, A. M., \& Fisher, P. A. (2019). Early adversity, child neglect, and stress neurobiology: From observations of impact to empirical evaluations of mechanisms. International Journal of Developmental Neuroscience Volume 78, 139-146.

Datulinggi, M., Thaha, M. R., Zulkifli, A., \& Mallongi, A. (2020). Risk factor sexual violence in children in Palopo city. Enfermería Clínica Volume 30, Supplement 4, 323-327.

Diaz, A., Shankar, V., Nucci-Sack, A., Linares, L. O., Salandy, A., Strickler, H. D., . . Schlecht, N. F. (2020). Effect of child abuse and neglect on risk behaviors in inner-city minority female adolescents and young adults. Child Abuse \& Neglect Volume 101.

Dinwiddie, S., Heath, A. C., Dunne, M. P., Bucholz, K. K., Madden, P. A., Slutske, W. S., . . Statham, D. B. (2000). Early Sexual Abuse and Lifetime Psychopathology: a Co-Twin-Control Study. Psychological Medicine No. 30 (1), 41-52.

DSM-IVTM. (1994). Diagnostic and statistical manual of mental disorders, fourth edition. Washington D.C: American Psychiatric Association.

Kurniasari, A., Wismaayanti, Y. F., Irmayani, Husmiati, Widodo, N., \& Susantyo, B. (2013). Survey Kekerasan Terhadap Anak Indonesia 2013. Jakarta: Kementerian Sosial, Kementerian Pemberdayaan Perempuan dan Perlindungan anak, Badan Perencanaan Pembangunan Nasional, Badan Pusat Statistik, UNICEF Indonesia.

Levitan, R. D., Rector, N. A., Sheldon, T., \& Goering, P. (2003). Childhood Adversities Associated with Major Depression and/or Anxiety Disorders Incommunity Sample of Ontario Issues of Co-Morbidity and Specifity. Depression \& Anxiety No. 17, 34-42.

Liel, C., Ulrich, S. M., Lorenz, S., Eickhorst, A., Fluke, J., \& Walper, S. (2020). Risk factors for child abuse, neglect and exposure to intimate partner violence in early childhood: Findings in a representative cross-sectional sample in Germany. Child Abuse \& Neglect Volume 106.

Liputan6com. (2020, Januari 12). Liputan6.com. Retrieved from Liputan6.com: https://www.liputan6.com/health/read/4153023/anak-juga-bisa-menjadi-pelakukekerasan-seksual

Mash, E. J., \& Wolfe, D. A. (2010). Abnormal child psychology fourth edition. USA: Wandsworth cengage learning. 
Moerti, W. (2019, Desember 31). merdeka.com. Retrieved from merdeka.com: https://www.merdeka.com/peristiwa/data-kpai-selama-2019-ada-123-anak-korbankekerasan-seksual-di-institusi-pendidikan.html

Nawawi, H., \& Martini, M. (1994). Penelitian Terapan. Yogyakarta: Gajahmada University.

Ngo, Q. M., Veliz, P. T., Kusunoki, Y., Stein, S. F., \& Boyd, C. J. (2018). Adolescent sexual violence: Prevalence, adolescent risks, and violence characteristics. Preventive Medicine Volume $116,68-74$.

Sattler, J. M. (2002). Assesment of Children (Behavioral and Clinical Applications). San Diego: Jerome M. Sattler, Publisher, Inc.

Sugiyono. (2012). Memahami Penelitian Kualitatif. Bandung: Alfabeta.

Sugiyono. (2012). Metode Penelitian Kuantitatif Kualitatif dan R\&D. Bandung: Alfabeta.

Supardan, D. (2009). Pengantar Ilmu Sosial Sebuah Kajian Pendekatan Struktural. Jakarta: Bumi Aksara.

Tonmyr, L., Williams, G., Hovdestad, W. E., \& Draca, J. (2011). Anxiety and/or depression in 1015-year-olds investigated by child welfare in Canada. Journal of Adolescent Health, 48, 493-498.

Tower, C. C. (2002). Understanding Child Abuse and Neglect. Boston: Allyn \& Bacon.

UNICEF. (2014). Hidden in Plain Sight: A Statistical Analysis of Violence against. New York: United Nations Children's Fund (UNICEF), Division of Data, Research and Policy.

Vanderminden, J., Hamby, S., David-Ferdon, C., Kacha-Ochana, A., Merrick, M., Simon, T. R., ... Turner, H. (2019). Rates of neglect in a national sample: Child and family characteristics and psychological impact. Child Abuse \& Neglect Volume 88, 256-265.

Wahyudi, M. Z. (2014, Mei 14). kompas.com. Retrieved from kompas.com: https://lifestyle.kompas.com/read/2014/05/14/1616274/Anak.Bisa.Jadi.Pelaku.Keker asan.Seksual?page $=$ all

Weber, M. R., \& Smith, D. M. (2010). Outcomes of Child Sexual Abuse as Predictors of laters Sexual Victimization. Journal of International Violence No. 26 (9), 1899-1905. 